\title{
A Study of Problem Based Learning Approach for Undergraduate Students
}

\author{
Jacob Jolly ${ }^{1} \&$ Cherian Jacob ${ }^{2}$ \\ ${ }^{1}$ Department of Applied Sciences, College of Arts and Sciences, Abu Dhabi University, Abu Dhabi, UAE \\ ${ }^{2}$ Department of Management, College of Business Administration, Abu Dhabi University, Abu Dhabi, UAE \\ Correspondence: Jacob Jolly, Department of Applied Sciences, College of Arts and Sciences, Abu Dhabi \\ University, Abu Dhabi, UAE. Tel: 971-2-586-0294. E-mail: jolly.jacob@adu.ac.ae
}

\author{
Received: August 4, 2012 Accepted: September 3, 2012 Online Published: November 30, 2012 \\ doi:10.5539/ass.v8n15p157 \\ URL: http://dx.doi.org/10.5539/ass.v8n15p157
}

\begin{abstract}
PBL approach is identified to develop both problem solving strategies and disciplinary knowledge bases and skills by means of subjecting the students to solve the problem offered to them. PBL is today considered to be unique as it promotes association among students, emphasizes the development of problem solving skills with respect to professional practices, develops effective reasoning and self directed learning. The main aim of this paper is to identify the importance of problem based learning in the form of identifying impact on student motivation by presenting a review of previously published work and arriving at a conclusion.
\end{abstract}

Keywords: problem based learning, student motivation, undergraduate education

\section{Introducation}

The characteristic features that are related to the complexity of the modern world is determined to be associated with infinite, dynamic information modification, excessive usage of internet, multimedia and educational technology. According to Nonaka \& Takeuchi, (1995) alterations in the labor market has a demand for flexible labor force. Encouraging the increase in number of knowledge intensive work in teams and lifelong learning is also associated with the characteristics of a complex community (Quinn, 1992; Tynjala, 1999).Hence the information community in modern world recommends that the graduates not only obtain theoretical knowledge but also have practical knowledge and implement it to solve complex tasks and operations (Engel, 1997; Poikela and Poikela, 1997; Segers, 1996). According to Chi, Glaser and Rees (1982), several academic research studies have identified efficient problem solvers who have flexible and organized knowledge in order to manage and apply the skills to solve a particular problem or aspect.

The student workload is assumed as a key aspect for designing a curriculum (Kember, 2004).In European Higher Education Area (EHEA), the qualification of a graduate is recommended based on the workload experienced by the student when considered to other aspects(EC, 2005). According to Kember (2004), the student workload can be related to the number of working hours that includes attending lectures, seminars or tutorials, independent and private study, preparation of projects, examinations etc. (EC, 2005). An examination of the workload of the students is vital when considering problem based learning as it enables identification of the possible tasks which need to be set and the time required by the faculty and the staff to complete these tasks.

Mandl, Gruber and Renkl (1996) criticized the educational system and practices as it does not enhance the conditions for developing professional expertise. The higher education system is determined to face a challenge of enhancing and embedding the instructional practices that cultivates in the student the skill to apply knowledge in order to solve a problem efficiently. With respect to the authors like De Corte, (1990a, 1990b); Honebein, Duffy \& Fishman, (1993); Tynjala, (1999) recommended the establishment of "powerful learning environments". The powerful learning environments should motivate and encourage the constructive cumulative and goal oriented process in students. De-Corte (1995) suggested that they should facilitate flexible adaption of the instructional support particularly for balancing self discovery and direct instruction.

Environments of such type are recommended to adapt to the representative authentic, real life situations that enable the learners to gain knowledge from personal life and provide chances for distributed and co-operative learning by means of social interactions. Boekaerts (1990a, 1990b) suggests that powerful learning environments 
should enable the students to achieve and gain the skills related to general thinking and learning that involves heuristic techniques, meta-cognitive knowledge and strategies. De-Corte (1995) recommends for the inclusion of environment in the subject matter. In this scenario the concepts of problem based learning which was presented to promote a better learning environment for learning among undergraduate students.

PBL can be defined as an instructional methodology that enables the students to understand the subjects in-depth The approach is identified to develop both problem solving strategies and disciplinary knowledge bases and skills by means of subjecting the students to solve the problem offered to them. The involvedment of PBL in undergraduate studies is of key importance because it enables identification of skills which the students should develop right at the entry level and identifies the probable methodology by needs assessment can be carried out. The students are assumed as problem solvers under certain circumstances based on the problem they are likely to solve as project managers in complex organizations. The main objective and aim of the process is to recognize the ability of the student to solve a problem and develop their learning and motivation skills. Students and teachers are considered as two key aspects for teaching of any kind. When a PBL approach is compared with traditional teaching method, the role and functions of the two roles are different. Teachers are defined as the educator guiding students to recognize and identify the key issues and problems related to the subject despite being experts in content. According to PBL approach, students are considered to have different roles and are the spirit. Students are recommended to provide their full participation in order to achieve the goal and objective of the expectations and both individually and as a team. Even though the students are observed as learners and are in the learning process, it does not mean that the teacher becomes a passive observer. Albanes(2000) recommends that the teachers are to be active in order to enable the students being involved in the course.

It is difficult to obtain at a relative measure of confirmation as to how PBL is beneficial when compared with the traditional methods (Stites, 1998). This is because there is no available methodology to empirically analyse the effect of each approach individually. There is a large degree of inconclusiveness associated with empirical designs that arise due to the control issues with the extraneous variables involved in them. The difficulty in controlling such extraneous variables also extends to those designs that are based on a comparative approach (Schmidt, 1990).

The variables associated with the student and instructor associated patterns are so closely interlinked that one cannot tease them apart and look at them in isolation. Thus comparisons are highly restricted across environmental variations with reference to education or learning based systems. While the traditional method focuses on mastering a subject matter and hence can be easily quantified, the PBL approach focuses on higher order thinking skills that cannot be accurately or effectively assessed through specific scoring patterns.

The PBL approach is defined in different specific aspects.

1) Based on the authentic tasks, issues and problems related to the real world are responsible for learning.

2) According to the course of PBL, the students and instructors are observed as co-planners, co-producers and co-evaluators as they are involved in the process of designing, implementation and refine their curriculum continuously.

The approach of PBL is related to the dynamic academic research studies that are concerned with learning and practices that promote it. The approach encourages the students to undertake the responsibility of learning as there are some lectures, no planned readings and activities like that. (Azer, 2000).

Thus PBL is today considered to be unique as it promotes association among students, emphasizes the development of problem solving skills with respect to professional practices, develops effective reasoning and self directed learning. The main aim of this paper is to identify the importance of problem based learning in the form of identifying impact on student motivation. This study is not restricted to any one region but aims at examining all literature available with respect to PBL and student motivation.

\section{Review of Literature}

\subsection{Principles of Problem Based Learning}

Based on the academic principles of Socratic teaching and constructivism, principles for problem based learning are framed and established. According to Socrates principle, questioning is the key aspect. The philosopher adapted to the approach in order to challenge the perspectives and evidences implemented by other researchers.The approach was also implemented in order to promote self-knowledge. According to Banning (2005), the Socratic educator collected the responses from the students by means of questioning. In order to determine the layers of the knowledge based on which it was developed, Socratic questioning was developed. As the educator avoids interacting with students based onrelated information, the approach is considered to be a 
complex method of teaching (Henson, 2003). The students are encouraged to make their own answers for the problems from their previous experience and illustrations rather than reciting the answers. Knowledge that is obtained from the previous experiences are to evaluated for the significance, combined together and synthesized for using along with novel problems. Hence it is determined to improve the critical thinking of the students which is considered as effective outcome and result of problem based learning (Oermann, 2004). Hence there is association between critical thinking theories and PBL approach.

The approach of Problem based learning (PBL) is an effective teaching and learning method that has been adapted by various educators since 5 decades. According to Savin-Baden and solving problemsdue to the PBL approach which is considered as conceptualized strategy. Students are offered with a problem for solving rather than providing them a lecture to absorb. Students when they work in team to solve a problem and attain experience and knowledge from the information they learn.

\subsection{Problem-based Learning versus Conventional Lecture-based Instruction}

Although new in some aspects, problem-based learning (PBL) is generally based on ideas that originated earlier and have been nurtured by different researchers (Ausubel, Novak, \& Hanesian, 1978; Bruner, 1959, 1961; Dewey, 1910, 1944; Piaget, 1954; Rogers, 1969). PBL, as it is known today, originated in the 1950s and 1960s. It grew from dissatisfaction with the common medical education practices in Canada (Barrows, 1996; Neufield \& Barrows, 1974). Nowadays PBL is developed and implemented in a wide range of domains. In spite of the many variations of PBL that have evolved, a basic definition is needed to which other educational methods can be compared. Six core characteristics of PBL are distinguished in the core model described by Barrows (1996).

First characteristic is that learning needs to be student-centered. Second, learning has to occur in small student groups under the guidance of a tutor. The third characteristic refers to the tutor as a facilitator or guide. Fourth, authentic problems are primarily encountered in the learning sequence, before any preparation or study has occurred. Fifth, the problems encountered are used as a tool to achieve the required knowledge and the problem-solving skills necessary to eventually solve the problem. Finally, new information needs to be acquired through self-directed learning. It is generally recognized that a seventh characteristic should be added: Essential for PBL is that students learn by analysing and solving representative problems. Consequently, a valid assessment system evaluates students' competencies with an instrument based on real life, i.e. authentic problems (Baxter \& Shavelson, 1994; Birenbaum, 1996; Shavelson, Gao, \& Baxter, 1996). The assessment of the application of knowledge when solving problems is the heart of the matter. Therefore, test items require examinees to apply their knowledge to commonly occurring and important problem-solving situations (Segers, Dochy, \& De Corte, 1999).

Much of the available literature has examined the levels of satisfaction among students and the confidence measures of students undergoing PBL. However, recent literature has seen that there is a direct effect of PBL on the intrinsic motivational aspect that deserves more attention as reviewed in this paper.

\section{Research Methodology and Proposed Research Questions}

In this review, the focus is laid on identifying the effects of PBL on motivational aspects are dealt with. Secondly, the impact of PBL on the knowledge pool and skill sets are assessed and weighed. In order to effectively write a review it is important to identify and integrate the available literature on the topic. Thus there is an element of bias associated with the location of such studies as it is imperative that one finds what one looks for and thus ultimately leads to a bias in the conclusions drawn from the findings. (Glass, McGraw, \& Smith, 1981 and Glass, 1976, p. 6).Thus in order to eliminate such biased conclusions, it is vital to include a thorough description of the procedural intricacies associated with literature research. Qualitative analyses were performed in order to study the specific phenomenon in detail by examining secondary published literature in depth and arriving at the conclusion to the proposed research question. The mathematical models or hypotheses were not used to identify the specific variable in qualitative analysis methods (Saunders et al., 2009). The proposed research question of the study is,

What is the effect of PBL on the intrinsic motivational aspect of undergraduate students?

Initially, the process of literature survey was begun from the computer-based sources such as databases including Sage, Wiley Online, Science Direct and JSTOR. The search terms used to mine data from these databases includes student motivation, PBL, knowledge building and skill building. After a brief run through of the abstracts, the relevant data were sorted and collected. Secondly, the references included in these articles were collected in a "snowball method" leading to generation of further research leads on similar criterion. Following this all the available reviews and theoretical writings on the subject were gathered. 


\subsection{Criteria for Inclusion}

Prior to literature survey on PBL, a few criterions were determined to select the relevant data for the study.

1) The empirical nature of the study was ascertained. Thus all sources that were not of an empirical design were not analysed.

2) The conformity of the learning environment considered in the paper was assessed to check if it fits with the aforementioned core model of problem based learning.

3) The variables assessed in the studies must include parameters based on knowledge acquisition or skill development on the basis of motivational aspects of PBL.

4) Finally, the student population included in the study must be at the higher education level.

\section{Discussion}

\subsection{PBL and Student Motivation}

The difference between the environment provided in the PBL and LB modules lie in the nature of the support system and the activity provisions to facilitate learning. Despite the variability within the curriculum drafted under a PBL format, the crux is basically the same. It is built on six core characteristics as explained by Barrows 1996, Hmelo- Silver 2004, and Schmidt et al., 2009. These include:

Firstly, the crux of PBL involves the creation of a learning mileu that is student-centered in nature. Secondly, student groups are encouraged as a learning medium. Thirdly, the tutor plays a guiding role. Fourthly, the process of learning is initiated through a problem which is presented to the student on the basis of what he or she has learnt before. Fifthly, large time investments are made for self-based studies. Lastly, very few lectures are made available in complement to self study procedures.

These characteristic traits significantly differentiate PBL from typical LB mileu which are designed to be teacher-centered. Further traditional methods are tailored to suit larger student populations at the same time posing constraints on the amount of student activity that can be incorporated in such a system (Kember 2009 and Lammers and Murphy, 2002).

Educational research advocates the self-determination theory as one of the most important frameworks for motivation. The reason behind this is the fact that in this method, differentiation is achieved among the reasons of autonomic origin that form the basis of the urge to learn (Guay et al., 2008, Ryan and Deci, 2000b, Pintrinch 2003b). Since autonomic reasoning is the product of voluntary choice, it aids in completely endorsed and willful participation in the activity under consideration which may range from interest-based and commitment-based study. Thus a self-driven behaviour is achieved that is fuelled by an intrinsic motivation at the best level possible. Apart from this, there are other sources of motivated behaviour such as extrinsic types that may also be categorized as autonomic. Although the reasons are extrinsic in nature, such pupils have an integrative approach towards their learning that is oriented in terms of personal goals, necessities and interests.

Although the prime aim of PBL involves the honing of such skills that enhance the internal motivation of a pupil to study (Hmelo-Silver, 2004 and Normal and Schmidt, 1992), several studies overlook this aspect and very few designs look at direct evaluation of motivation at the intrinsic level with reference to PBL.

\subsection{Studies Impacting Motivation of Student}

Deci and Ryan, (2000) identified that working towards an important goal in life such as a professional orientation will lead to increased voluntary and willful effort on the student's part in terms of his or her studies. However, the concept of controlled behaviour differs from the aforesaid as it is governed by pressures of some nature. These pressures may be intrinsic such as feelings of guilt or shame or extrinsic such as demands of parents, peers etc. Thus there is a controlled study pattern where motivation is achieved by extrinsic regulation. Thus it can be said that the concept of autonomous motivation comprises of motivation of both intrinsic and extrinsic nature

Schmidt et al., (2009) showed that medical learning instituted in a PBL format was much more effective in terms of learning in the perspective of the students. It was found that such studies helped students and professionals to acquire and present better interpersonal and practical skills in comparison with the traditional ways of learning. Further very less drop-outs were associated with PBL when compared with traditional curriculum. In tandem with these results, the number of successful and faster course completion were also higher among PBL students. Finally, results also showed that the PBL curriculum was rated to be of higher quality than the traditional curriculum resulting in higher student satisfaction and quality index. 
Blumberg, (2000) In a study identified the effects of self directed learning were assessed in terms of whether or not they stem from an intrinsic potential of PBL learners and its contribution to the motivational aspect of the student. The organization of this study included three different planes namely, the process of learning, the strategies employed and the outcomes achieved. Apart from this there was a crucial distinction in terms of the investigation of SDL in terms of a holistic concept or in terms of its comprising skills such as learning definitions or plans. Finally, there was also a brief analysis of the data type involved whether it was self-reported, performance measures or faculty-based reports.

Mergendoller, Maxwell, and Bellisimo, (2000) in another quasi-experiment study conducted, comparisons were drawn between the amount of knowledge acquired by students against their attitudinal differences in terms of approaching the subject: in this case, economics. Results obtained indicated that in terms of knowledge acquisition, traditional methods resulted in more content-based knowledge than PBL approaches. However, irrespective of the learning method opted, the intrinsic motivational aspects of the student played a more crucial role in terms of the knowledge acquisition achieved than the mode of learning or teaching itself.

Noordzij and Te Lindert (2010) identified that it has been shown that motivation is directly proportional to the quality of a problem. Further the more intrinsically motivated a student was, the higher the interest he or she showed towards the problem. S

Liu et al., (2006) has also shown that it is possible in enhance the motivational orientation of students through PBL and quasi-experimental interventions. The enhanced motivational paradigms were also associated with increased beliefs of self-efficacy and capability with reference to future tasks of a similar nature.

In the study by Martin et al., (2008) it has also been shown that undergoing PBL approaches for a period of 12 weeks, significantly influences the intrinsic motivation of the students. On the other hand there were no significant effects of PBL on the levels of extrinsic motivation of the students or measures of self-esteem amongst PBL learners. However in another similar study, undergoing PBL based computer engineering courses for a period of 16 weeks significantly increased the self efficacy of the students (Dunlap 2005).

Studies have also shown that comparative analysis between PBL and conventional learners indicate that PBL learners are more goal-oriented, receptive of task value and motivated (Sungur and Tekkaya (2006; Hwang and Kim (2006).

Sierens et al., Dochy (2009) have shown that when a structural framework is provided in a manner that supports autonomy, it results in an enhanced measure of self-directedness in terms of learning and motivation. The presence of a structure enables the instructors to enforce a regulatory role on the study pursued, apart from playing a guiding role in terms of feedbacks and critical analysis. This in turn enables to boost the competence of the student and motivate them. But when structure is provided in a controlled fashion it does not influence motivational aspects. Since there are no variations among the parameters of autonomous and controlled motivation among students in either learning type, it can enable us to arrive at an explanation as to the lack of differenced among the SRL in terms of strategic monitoring methods.

In a recent study by Wijlinia et al., (2011) identified that the influence of problem-based and lecture-based learning methods on the motivation of a student were studied. Results obtained have shown that both autonomous and controlled forms of motivation behaviour are unaltered irrespective of the learning method adopted. However, the perception of student competence was higher among PBL learners when compared with LB learners. On the other hand, there was a perceived imbalance of controlling factors and autonomous elements among the PBL students. Hence it is crucial that the learning style must incorporate the perfect amount of control through structural incorporations.

In another study, qualitative analysis of data gathered from medical students transitioning from LB to PBL showed that most students experienced difficulties during the transition (C.B. White 2007). However, once accustomed to PBL, there was an increased comfort level associated with the autonomy and responsibility associated with PBL. When the time came for transition from classroom to clerkships PBL students were more effective in easing into their new roles against conventional learners. Thus the study is suggestive of the role of PBL in enhancing the motivation of the student.

\section{Conclusion}

Studies on PBL induced motivational effects have their own limitations and constraints as most studies do not conform to the existing PBL curricula. Another limitation was that the incorporation of PBL was for a short time and only for one of the courses offered. Thus most research can be classified as intervention-based or quasi-experimental. However, there are certain unique characteristics of PBL such as the guidance of a tutor, 
incorporation of problems, feedback regulation collaborative efforts etc. that can enhance the motivation of the student and SRL. But there is the problem of a stressful experience if PBL lacks the adequate structural framework as it would lead to enhanced responsibility and attribution of failure to insufficiency or inability.

From the above discussion it can be identified that future research direction should focus on the development of fair and efficient instruments that aid measurements of student participation and work outcomes in terms of identification of student motivation. Although there are challenges in team projects, they are crucial experiences that are essential to shift the focus from grades.

\section{References}

Albanese, M. (2000). Problem-based Learning: Why Curricula are Likely to Show Effect on Knowledge and Clinical Skills. Medical Education, 34, 729-738. http://dx.doi.org/10.1046/j.1365-2923.2000.00753.x

Ames, C. (1992). Classroom: Goals, structures, and student motivation. Journal of Educational Psychology, 82, 261-271. http://dx.doi.org/10.1037/0022-0663.84.3.261

Assor, A., Kaplan, H., \& Roth, G. (2002). Choice is good, but relevance is excellent: Autonomy-enhancing and suppressing teacher behaviours predicting students' engagement in schoolwork. British Journal of Educational Psychology, 72, 261-278. http://dx.doi.org/10.1348/000709902158883

Ausubel, D., Novak, J., \& Hanesian, H. (1978). Educational Psychology: A Cognitive View (2nd ed.). NewYork: Holt, Rinehart \& Winston.

Azer, S. A. (2000). Arterial disease in antiquity. Medical Journal of Australia, 199, 171-280.

Banning, M. (2005). Approaches to teaching: current opinions and related research. Nurse Education Today, 25, 502-508. http://dx.doi.org/10.1016/j.nedt.2005.03.007

Barrows, H. S. (1996). Problem-based learning in medicine and beyond: a brief overview. New Directions for Teaching and Learning, 68, 3-12. http://dx.doi.org/10.1002/t1.37219966804

Baxter, G. P., \& Shavelson, R. J. (1994). Science Performance Assessments: Benchmarks and Surrogates. $\begin{array}{llll}\text { International Journal of Educational 279-299. } & \text { Rearch, }\end{array}$ http://dx.doi.org/10.1016/S0883-0355(06)80020-0

Birenbaum, M. (1996). Assessment 2000: Towards a Pluralistic Approach to Assessment. In M. Birenbaum, \& F. J. R. C. Dochy (Eds.), Alternatives in Assessment of Achievements. Learning Processes and Prior Knowledge (pp. 3-29). Boston: Kluwer Academic Press. http://dx.doi.org/10.1007/978-94-011-0657-3_1

Black, A. E., \& Deci, E. L. (2000). The effects of instructors' autonomy support and students' autonomous motivation on learning and organic chemistry: A self-determination theory perspective. Science Education, 84, 740-756. http://dx.doi.org/10.1002/1098-237X(200011)84:6<740::AID-SCE4>3.0.CO;2-3

Blumberg, P. (2000). Evaluating the evidence that problem-based learners are self-directed learners. In D. H. Evensen, \& C. E. Hmelo (Eds.), Problem-based learning: A review of the literature: A research perspective on learning interactions (pp. 199-226). Lawrence Erlbaum, Mahwah, NJ.

Blumenfeld, P. C. (1992). Classroom learning and motivation: Clarifying and expanding goal theory. Journal of Educational Psychology, 84, 272-281. http://dx.doi.org/10.1037/0022-0663.84.3.272

Boekaerts, M. (1990a). Self-regulated learning. Where are we today? International Journal of Educational Research, 31, 445-457. http://dx.doi.org/10.1016/S0883-0355(99)00014-2

Boekaerts, M. (1990b). Motivated learning: The study of student x situation transactional units. European Journal of Psychology of Education, 14(4), 41-55.

Bruner, J. S. (1959). Learning and thinking. Harvard Educational Review, 29, 184-192.

Bruner, J. S. (1961). The act of discovery. Harvard Educational Review, 31, 21-32.

De Corte, E. (1990a). A State -of-the-art of research on learning and teaching. In Keynote lecture presented at the first European Conference on the First Year Experience in Higher Education (pp. 23-25). Denmark: Aalborg University.

De Corte, E. (1990b). Toward powerful learning environments for the acquisition of problem-solving skills. European Journal of Psychology of Education, 5(1), 5-19. http://dx.doi.org/10.1007/BF03172765

De Corte, E. (1995). Cognitive growth: A perspective from research on mathematics learning and instruction. Educational Psychologist, 30(1), 37-46. http://dx.doi.org/10.1207/s15326985ep3001_4

Dewey, J. (1910). How we think. Boston: Health \& Co. http://dx.doi.org/10.1037/10903-000 
Dewey, J. (1944). Democracy and education. New York: Macmillan Publishing Co.

Duke, M., Forbes, H., Hunter, S., \& Prosser, M. (1998). Problem-based learning (PBL): Conceptions and approaches of undergraduate students of nursing. Advances in Health Sciences Education, 3, 59-70. http://dx.doi.org/10.1023/A:1009763324321

Dunlap, J. C. (2005). Problem-based learning and self-efficacy: How a capstone course prepares students for a profession. Educational Technology Research and Development, 53, 65-85. http://dx.doi.org/10.1007/BF02504858

Engel, C. E., (1997). Not just a method but a way of learning. In D. Boud, \& G. Feletti (Eds.), The challenge of problem based learning (2nd ed., pp. 17-27). London: Kogan.

European Commission, EC., (2005a). From Berlin to Bergen. General progress report, Available at: Brussels: $\begin{array}{lllll}\text { A2/PVDH. } & \text { Retrieved } & \text { April } & 7, & \text { 2005, }\end{array}$ http://europe.eu.int/comm/education/policies/educ/bologna/report05.pdf

Glass, G. V. (1976). Primary, secondary and meta-analysis. Educational Researcher, 5, 3-8.

Glass, G. V., McGaw, B., \& Smith, M. L. (1981). Meta-analysis in social research. London: Sage Publications.

Guay, F., Ratelle, C. F., \& Chanal, J. (2008). The role of self-determination in education Canadian Psychology. Optimal learning in optimal contexts, 49, 233-240.

Henson, K. T. (2003). Foundations for learner centered education', a knowledge base. Education, 124, 5-17.

Hmelo-Silver, C. E. (2004). Problem-based learning: What and how do students learn? Educational Psychology Review, 16, 235-266. http://dx.doi.org/10.1023/B:EDPR.0000034022.16470.f3

Honebein, P. C., Duffy, T. M., \& Fishman, B. J. (1993). Constructivism and the design of learning environments: context and authentic activities for learning. In T. M. Duffy, J. Lowyck, \& D. H. Jonassen (Eds.), Designing environments for constructive learning (pp. 87-108). Heidelberg, Germany: Springer-Verlag Berlin. http://dx.doi.org/10.1007/978-3-642-78069-1_5

Hwang, S. Y., \& Kim, M. J. (2006). A comparison of problem-based learning in an adult health nursing course. Nurse Education Today, 26, 315-321. http://dx.doi.org/10.1016/j.nedt.2005.11.002

Kember, D. (2004). Interpreting student workload and the factors which shape students' perceptions of their workload. Studies in Higher Education, 29(2), 165-184. http://dx.doi.org/10.1080/0307507042000190778

Kember, D. (2009). Promoting student-centered forms of learning across an entire university. Higher Education, 58, 1-13. http://dx.doi.org/10.1007/s10734-008-9177-6

Lammers, W. J., \& Murphy, J. J. (2002). A profile of teaching techniques used in the university classroom. Active Learning in Higher Education, 3, 54-67. http://dx.doi.org/10.1177/1469787402003001005

Liu, M., Hsieh, P., Cho, Y., \& Schallert, D. L. (2006). Middle school students' self-efficacy, attitudes, and achievement in a computer-enhanced problem-based learning environment. Journal of Interactive Learning Research, 17, 225-242.

Mandl, H., Gruber, H., \& Renkl, A. (1996). Communities of practice toward expertise: Social foundation of university instruction. In P. B. Baltes, \& U. M. Staudinger (Eds.), Interactive minds: Life-span perspectives on the social foundation of cognition (pp.394-412). Cambridge, UK: Cambridge University Press.

Martin, L. J., West, J., \& Bill, K. (2008). Incorporating problem-based learning strategies to develop learner autonomy and employability skills in sports science undergraduates. Journal of Hospitality, Leisure, Sport \& Tourism Education, 7, 18-30. http://dx.doi.org/10.3794/johlste.71.169

Mergendoller, J., Maxwell, N., \& Bellisimo, Y. (2000). Comparing problem-based learning and traditional instruction in high school economics. The Journal of Educational Research, 93(6), 374-382. http://dx.doi.org/10.1080/00220670009598732

Neufeld, V., \& Barrows, H. (1974). The McMaster philosophy: An approach to medical education. Journal of Medical Education, 49, 1040-1050.

Nonaka, I., \& Takeuchi, H. (1995). The knowledge-creating company. New York: Oxford University Press.

Noordzij, G., \& Te Lindert, A. (2010). The effects of goal orientation and quality of problems on students' motivation in a problem based learning environment. Poster presented at the self-determination theory conference, Belgium: Gent.

Norman, G. R., \& Schmidt, H. G. (1992). A review of the evidence Academic Medicine. The psychological basis of problem-based learning, 67, 557-565. 
Oermann, M. H. (2004). Using active learning in lecturer: best of both worlds. International Journal of Nursing Education Scholarship, 1.

Piaget, J. (1954). The construction of reality in the child. New York: Basic Books. http://dx.doi.org/10.1037/11168-000

Pintrich, P. R. (2003). A motivational science perspective on the role of student motivation in learning and teaching contexts. Journal of Educational Psychology, 95, 667-686. http://dx.doi.org/10.1037/0022-0663.95.4.667

Pintrich, P. R., \& Schunk, D. H. (2002). Motivation in education: Theory, research, and applications. Prentice Hall Merrill: Upper Saddle River, NJ.

Poikela, E., \& Poikela, S. (1997). Conceptions of learning and knowledge-impacts on the implementation of problem-based learning. Zeitschrift fur Hochschuldidactik, 1, 8-21.

Quinn, J. B. (1992). Intelligent enterprise, a knowledge and service based paradigm for industry. New York: The Free Press.

Rogers, C. R. (1969). Freedom to Learn. Colombus, Ohio: Charles E. Merill Publishing Company.

Ryan, R. M., \& Deco, E. L. (2000). Self-determination theory and the facilitation of intrinsic motivation, social $\begin{array}{lllll}\text { development, and } \quad \text { well-being. } & \text { American }\end{array}$ http://dx.doi.org/10.1037/0003-066X.55.1.68

Schmidt, H. G., Norman, G. R., \& Boshiuzen, H. P. A. (1990). A cognitiveperspective on medical expertise: Theory and implications. AcademicMedicine, 65, 611-621. http://dx.doi.org/10.1097/00001888-199010000-00001

Schmidt, H. G., Van der Molen, H. T., Te Winkel, W. W. R., \& Wijnen, W. H. F. W. (2009). Constructivist, problem-based learning does work: A meta-analysis of curricular comparisons involving a single medical school. Educational Psychologist, 44, 227-249. http://dx.doi.org/10.1080/00461520903213592

Segers, M. S. R. (1996). Assessment in a Problem-Based Economics Curriculum. In M. Birenbaum, \& F.J.R.C. Dochy (Eds.), Alternatives in Assessment of Achievements, Learning Processes and Prior Knowledge. Boston/Dordrecht/London: Kluwer Academic Publishers. http://dx.doi.org/10.1007/978-94-011-0657-3_8

Segers, M., Dochy, F., \& De Corte, E. (1999). Assessment practices and students' knowledge profiles in a problem-based curriculum. Learning Environments Research, 2, 191-213. http://dx.doi.org/10.1023/A:1009932125947

Shavelson, R. J., Gao, X., \& Baxter, G. P. (1996). The content validity of performance assessments: Centrality of domain specification. In M. Birenbaum, \& F. Dochy (Eds.), Alternatives in assessment of achievements, learning processes and prior learning (pp. 131-143). Boston: Kluwer Academic Press. http://dx.doi.org/10.1007/978-94-011-0657-3_5

Sierens, E., Vansteenkiste, M., Goossens, L., Soenens, B., \& Dochy F. (2009). The synergistic relationship of perceived autonomy support and structure in the prediction of self-regulated learning. British Journal of Educational Psychology, 79, 57-68. http://dx.doi.org/10.1348/000709908X304398

Stites, R. (1998). What does research say about outcomes from project-based learning? SRI International, Menlo Park, California. Retrieved March, 2006, from http://pblmm.k12.ca.us/PBLGuide/pblresch.htm

Sungur, S., \& Tekkaya, C. (2006). Effects of problem-based learning and traditional instruction on self-regulated learning. The Journal of Educational Research, 99, 307-317. http://dx.doi.org/10.3200/JOER.99.5.307-320

Tynjälä, P. (1999). Towards expert knowledge? A comparison between a constructivist and a traditional learning environment in the University. International Journal of Educational Research, 33, 355-442.

White, C. B. (2007). Smoothing out transitions: how pedagogy influences medical students achievement of self regulated learning goals. Advances in Health Science Education, 12, 279-97. http://dx.doi.org/10.1007/s10459-006-9000-z

Wijinia, L., Loyens, S. M. M., \& Derous, E. (2011). Effects of problem-based versus lecture based learning environments on student motivation. Contemporary Educational Psychology, 36, 101-113. http://dx.doi.org/10.1016/j.cedpsych.2010.11.003

Zimmerman, B. J., \& Campillo, M. (2003). Motivating self-regulated problem solvers. In J. E. Davidson, \& R. J. Sternberg (Eds.), The psychology of problem solving (pp. 233-262). New York: Cambridge University Press. http://dx.doi.org/10.1017/CBO9780511615771.009 